\title{
E-working: Country Versus Culture Dimension
}

Michal Beňo

Institute of Technology and Business in Ceske Budejovice, Czech Republic

\begin{abstract}
Globalisation and increasing digitisation mean that companies must increasingly orientate themselves internationally in order to become (more) competitive or to remain competitive. Promoting e-working can revitalise rural development. The issue involved is always interaction between people from different cultures, between people who, according to their cultural backgrounds, feel, think and act differently. When cultural diversity and differences are taken into account, greater creativity, more diverse ideas and faster problem solving are achieved. The cultural dimensions, according to Geert Hofstede, offer a comprehensive model for capturing the various expressions of intercultural values. This paper examines the motives for applying e-working in selected European countries in 2018 according to Hofstede's six dimensions of national culture. Twenty-eight countries from the Eurostat database were analysed (Finland and the Netherlands were excluded, and software detected them in the e-working variable as outliers). Correlation with e-working is statistically significant at PDI (power distance index - negative: the lower the PDI index, the higher the proportion of e-working) and IVR index (indulgence versus restraint - positive: the higher the IVR index, the higher the proportion of e-working).
\end{abstract}

\section{Keywords}

E-working, country versus culture, Hofstede, six dimensions of national culture.

Beňo, M. (2021) "E-working: Country Versus Culture Dimension", AGRIS on-line Papers in Economics and Informatics, Vol. 13, No. 2, pp. 23-34. ISSN 1804-1930. DOI 10.7160/aol.2021.130202.

\section{Introduction}

How people live, work, communicate and spend their money has changed dramatically over the centuries. Rural territories face significant challenges in a globalised world as the jobs available in traditional rural sectors are decreasing (Vitola and Baltina, 2013). Consequently, the global rural population is decreasing (WorldBank, 2018). Young, educated and qualified people are the first to leave because of the lack of challenging jobs in the rural areas (Vitola and Baltina, 2013). E-working is on an uneven, upward trend. The number of e-workers is generally increasing (IWG, 2019; Vilhelmson and Thulin, 2016) thanks to technology development and in particular high-speed broadband (Beňo, 2018a; Messenger and Gschwind, 2016), which facilitates much nine to five work to be performed remotely or away from the office. Further factors that drive e-working are long commuting times, the rise of gig-economy employment opportunities, work-life-balance demands and the spread of Covid-19. Generally, e-working makes employees happy, and satisfied employees are usually more productive (Beno and Hvorecky, 2021). In particular, two main factors are responsible: 1) the availability of digital connectivity and 2) the proportion of workers employed in industries and occupations that are amenable to remote work. Recent research reports reveal that rural countries face more challenges in building a remote workforce because they suffer from high rates of unemployment and have fewer educated workers (Gallardo and Florida, 2020).

But different working cultures also lead to different expansions of e-working. Some cultural aspects that play a role here are social behaviour (independence/teamwork), communication, interaction and openness towards new methods and models. It is generally held that people working in Nordic countries are socially more independent and have functional interaction. In Finland, flexible work has been part of the working culture for more than two decades. It is a way of working that meshes well with the deeply rooted culture of trust, equality and pragmatism in the country. In Scandinavia, there are relatively flat organisations, low hierarchies and pragmatism, which are important features for possible flexibility 
(Savage, 2019). The UK is more progressive, as far as new working methods are concerned, compared to other countries. Bettina von Stamm of the London Business School states that the key to successful remote working is self-confidence, delegated authority and autonomy that are supported by the British style of management (BBC, 2000). Managers in France still give importance to the size and position of the office. There is a kind of social-space contract, which means that promotion is related to the space (Soyez, 2019). Going to work is a generalised symbol of status in the Eastern European environment. Another factor that has to be taken into account is whether the current culture of the organisation supports e-working.

Culture is a complex and broad set of relationships, values, attitudes, practices, behaviours and beliefs that bind a specific group of people. Hofstede himself provides equivocal definitions: "A collective programming of the mind which distinguishes one group from another" (Hofstede 1980); "Mental programming ... patterns of thinking and feeling and potential acting" (Hofstede, 1991). Culture is not something that is simply gained; it is a slow process of growing into a society (Alony and Jones, 2007). Research by Brennan et al. (2009) illustrates the links between local culture and community development. For example, the idea of a good work-life balance is ingrained in Finnish culture. The rural residences, to which city dwellers regularly uproot themselves to enjoy the Nordic countryside, are embedded in Finnish life (Bishop, 2020).

Geert Hofstede is one of the leading academics on culture (Søndergaard, 1994; Kirkman et al., 2006; Merkin et al., 2014; Dimitrov, 2014).
Based on his analysis of the dataset, he initially distinguished four (power distance, collectivism versus individualism, femininity versus masculinity, uncertainty avoidance), later five (including longterm orientation versus short-term orientation) and finally even six (indulgence versus restraint) dimensions of cultural orientation that are different for various national cultures (Hofstede, 1980, 1991; Hofstede et al., 2010).

The main goal of this paper was to examine motives as they apply to e-working within selected European countries in 2018 and in terms of Hofstede's six dimensions of national culture. Correlations were used to find answers to the following research questions: Does diversity of national cultures affect the scope of e-working agreements? What causes a higher level of e-working in selected countries? Are there significant correlations between percentages and numbers of e-workers for PDI (power distance), IDV (collectivism versus individualism), MAS (femininity versus masculinity), UAI (uncertainty avoidance), LTOWVS (short-term/long-term orientation) and IVR (indulgence versus restraint)?

The following section briefly outlines the methodology used in this research. The third section provides an account of the e-working concept. The fourth section gives a short overview of results and closes with a discussion. The last section gives the conclusions.

\section{Materials and methods}

The descriptive statistics method was used to analyse and describe the basic features of the data in developing results and drawing conclusions, and the information processed in Table 1 was identified and summarised.

\begin{tabular}{|l|c|c|c|c|c|c|c|}
\hline Country & PDI & IDV & MAS & UAI & LTOWVS & IVR & e-working \\
\hline Austria & 11 & 55 & 79 & 70 & 60 & 63 & 10 \\
\hline Belgium & 65 & 75 & 54 & 94 & 82 & 57 & 6.6 \\
\hline Bulgaria & 70 & 30 & 40 & 85 & 69 & 16 & 0.3 \\
\hline Croatia & 73 & 33 & 40 & 80 & 58 & 33 & 1.4 \\
\hline Czech Republic & 57 & 58 & 57 & 74 & 70 & 29 & 4 \\
\hline Denmark & 18 & 74 & 16 & 23 & 35 & 70 & 7.6 \\
\hline Estonia & 40 & 60 & 30 & 60 & 82 & 16 & 7.6 \\
\hline Finland & 33 & 63 & 26 & 59 & 38 & 57 & 13.3 \\
\hline France & 68 & 71 & 43 & 86 & 63 & 48 & 6.6 \\
\hline Germany & 35 & 67 & 66 & 65 & 83 & 40 & 5 \\
\hline Great Britain & 35 & 89 & 66 & 35 & 51 & 69 & 4.4 \\
\hline Greece & 60 & 35 & 57 & 112 & 45 & 50 & 2 \\
\hline
\end{tabular}

Source: Author's own compilation (based on Eurostat, 2019 and Hofstede, 2015).

Table 1: Hofstede's dimension indexes and e-working percentage of selected countries (to be continued). 


\begin{tabular}{|l|c|c|c|c|c|c|c|}
\hline Country & PDI & IDV & MAS & UAI & LTOWVS & IVR & e-working \\
\hline Hungary & 46 & 80 & 88 & 82 & 58 & 31 & 2.3 \\
\hline Italy & 50 & 76 & 70 & 75 & 61 & 30 & 3.6 \\
\hline Ireland & 28 & 70 & 68 & 35 & 24 & 65 & 6.2 \\
\hline Latvia & 44 & 70 & 9 & 63 & 69 & 13 & 2.9 \\
\hline Lithuania & 42 & 60 & 19 & 65 & 82 & 16 & 2.5 \\
\hline Luxembourg & 40 & 60 & 50 & 70 & 64 & 56 & 11 \\
\hline Malta & 56 & 59 & 47 & 96 & 47 & 66 & 5.8 \\
\hline The Netherlands & 38 & 80 & 14 & 53 & 67 & 68 & 14 \\
\hline Norway & 31 & 69 & 8 & 50 & 35 & 55 & 5.5 \\
\hline Poland & 68 & 60 & 64 & 93 & 38 & 29 & 4.6 \\
\hline Portugal & 63 & 27 & 31 & 104 & 28 & 33 & 6.1 \\
\hline Romania & 90 & 30 & 42 & 90 & 52 & 20 & 0.4 \\
\hline Slovakia & 104 & 52 & 110 & 51 & 77 & 28 & 3.6 \\
\hline Slovenia & 71 & 27 & 19 & 88 & 49 & 48 & 6.9 \\
\hline Spain & 57 & 51 & 42 & 86 & 48 & 44 & 4.3 \\
\hline Sweden & 31 & 71 & 5 & 29 & 53 & 78 & 5 \\
\hline
\end{tabular}

Source: Author's own compilation (based on Eurostat, 2019 and Hofstede, 2015).

Table 1: Hofstede's dimension indexes and e-working percentage of selected countries (continuation).

To determine the existence of dependency between e-working and individual dimensions, Pearson's correlation coefficient was applied. Three different types of correlation can be categorised, namely positive correlation, the other variable also has a tendency to increase; negative correlation, the other variable has a tendency to decrease and no correlation, the other variable does not tend to increase or decrease. Before it was applied, the normality of the data was verified by the ShapiroWilk test and fulfilment of the second condition, linear relation, using the regression analysis.

Using correlations, answers were sought for the research questions: Does diversity of national cultures influence the scope of e-working agreements? What causes a higher level of e-working in selected countries? Are there significant correlations between percentages and numbers of e-workers for PDI (power distance), IDV (collectivism versus individualism), MAS (femininity versus masculinity), UAI (uncertainty avoidance), LTOWVS (short-term/long-term orientation) and IVR (indulgence versus restraint)?

\section{The meaning of e-working}

"Flexible working arrangements" or "e-working" are replacing a range of different terms, such as "teleworking", "telecommuting", "networking", "digital nomad" and "flexi space", which seek to describe the ways in which new information and communication technologies have made it possible for information-processing work to be carried out at a distance (Bates et al., 2002). The classic definition of teleworking is outdated (Beno, 2018b). Currently, there is no international statistical definition.

Basically, e-work means the utilisation of ICT (Information and Communication Technology) rather than commuting to work (Beňo and Ferenčíková, 2019). Also, e-work is a method of working using ICT in which the work is not bound to any particular location. Traditionally this has been understood as working remotely from the office, usually from home, whether full-time or for a part of the working week (WDC, 2017). E-working is where employees work at home full-time/part-time, on a hybrid basis or at a different place or virtually. This kind of work involves logging into a work computer remotely (using a virtual private network, e.g. Cisco, Barracuda), sending and receiving email, data and files remotely and developing ideas, products and services, as well as learning remotely and performing other remote business activities. To conclude, e-working is a practical approach to accomplish business objectives. This kind of work allows organisations in the private and public sectors to operate remotely, while employees are absent from their physical workspaces.

The father of e-working is considered to be Jack Nilles (Beno, 2018b). ICT plays an essential role in the spread of work and e-working. The Dunn (2009a, 2009b) and Frempong (2009) studies used 
telework as an example of what can be achieved by mobile phone technology innovations. A similar study is by Plauché and Prabaker (2006) on a speech-driven agricultural query system. Though not mobile technology based, it showed how queries can be sent to remote systems, hence proving that it is possible to innovate by using telephones for remote-related actions even with low-literacy levels. ICT allow us to connect not only physically but also virtually. Thus ICT can serve as an important tool to overcome the distance in rural areas and to take full advantage of its resources and further possibilities. The Covid-19 pandemic creates an e-working tipping point. E-working helped to sustain economic activity. Millions of people around the world must now work from home. Obviously, there is no consensus in economics literature about the impact on productivity while working remotely. Beno and Hvorecky (2021) indicate that a workforce that does not feel comfortable with e-work tends to be less productive. Managers face an increasing need for solutions to maximise online technologies to support employee satisfaction.

Computer and communications technology may make it possible for more jobs to be performed remotely (Olson, 1983). Through various technological advancements, e-working facilitates a flexible workplace in which the workforce has options about the structure of its work time (Pearce, 2009). In a remote work environment, various primary instruments (from emailing to face-to-face meetings and video conferences) are used (Kirkman and Mathieu, 2005; Mihhailova et al., 2009). Emailing is viewed as an analytic task approach. Additionally, desktop video-conferencing, collaborative software and Internet/intranet systems evolved into fundamental infrastructure for the modern workplace environment (Becke et al., 2001). Karpova et al. (2009) suggested that synchronous media such as videoconferencing are suitable for stating problems and giving crucial decisions, whereas others such as collaborative document management tools (e.g. Google Docs) are more suited to tasks such as information flow and the organising of tasks across the team. Conference tools (such as instant messaging, audio-/ videoconferencing) aid e-workers' collabration and the exchange of ideas and information in person (Karoui et al., 2010). Connectivity, IT infrastructure and communcation tools were identified as the most important aids for remote work (PWC, 2020). To improve communication within the team (on-site or remote), the utilisation of online collaboration tools should be considered
(Ye, 2012). The effectiveness of a collaboration tool relies on whether the tool is relevant to the stage of collaboration (Kalika and Jawadi, 2008). Furthermore, computer-mediated communcation has become mainstream in work life (Derks and Bakker, 2010).

Being away from the office in a hybrid setting that means a change of place, country and approach with employees working entirely in a cubicle and/or remotely or in a comfortable setting (at home, or mobile) has benefits (saving time and money, flexibility and autonomy, productivity, less commuting, fewer distractions, work-lifebalance and many others) and limitations (difficulty in separating home and work life, domestic distractions and interruptions, feelings of isolation and loneliness, workaholism, etc.). E-working has the following positive and negative impacts: economic, environmental, personal and social - the so-called triple-win option (Beňo, 2021a) for employers, employees and society (Beňo and Ferenčíková, 2019).

Brette and Moriset (2009) emphasise that today's economy is subject to a tension between centrifugal and centripetal forces, the outcome of which is uncertain. As e-working continues to accelerate, there are a number of likely implications, challenges and opportunities that arise in the Covid-19 crisis. We are of the opinion that e-working has created new opportunities for rural development, as stated in a recent study on housing (Beno, 2021b). According to the latest data, interest in rural areas and small towns increased during the coronavirus outbreak (Redfin, 2020). Further, e-working can reverse the rural brain drain (Sisson, 2019). The digital economy offers home-based microbusinesses in rural areas many advantages, but stubborn social, economic and territorial digital divides continue to create challenges for this sector of the rural economy (Philip and Williams, 2019). As mentioned before, there are potential direct and indirect benefits and risks. However, the paradox of e-working is that it includes the implication of investment in ICT, which tends to be located in large urban centres. This can prove challenging for rural communities that are struggling with declining populations and rising unemployment. E-working has been seen as a potential solution for rural development, but it remains a privileged urban and suburban phenomenon. This is confirmed by Davies's (2021) statement that for some rural areas and populations, the urban-rural digital divide persists as a barrier to participation in ICTsupported remote working. 


\section{Results and discussion}

A very effective method for analysis of relations between dimensions and e-working is multiple regression. The quality of the model is high, and the determination index takes the values close to 1 , as seen in Table 2 .

\begin{tabular}{|c|c|c|c|c|}
\hline \multicolumn{5}{|c|}{ Model Summary } \\
\hline Model & $\mathbf{R}$ & R Square & $\begin{array}{l}\text { Adjusted } \\
\text { R Square }\end{array}$ & Std. Error of the Estimate \\
\hline 1 & $\mathbf{. 9 3 2}^{\mathrm{a}}$ & .869 & .830 & 2.273 \\
\hline
\end{tabular}

Note: a... Predictors: ivr, pdi, mas, ltowvs, uai, idv

b.. For regression through the origin (the no-intercept model), R Square measures the proportion of the variability in the dependent variable about the origin explained

by regression. This CANNOT be compared to R Square for models which include an intercept.

Source: Author's own compilation.

Table 2: Model summary.

The overall test of the model is also very significant $(\mathrm{p}<0.05)$, see Table 3 .

\begin{tabular}{|r|c|c|c|c|c|}
\hline \multicolumn{7}{|c|}{ ANOVA $^{\mathrm{a}, \mathrm{b}}$} \\
\hline Model & $\begin{array}{c}\text { Sum } \\
\text { of Squares }\end{array}$ & $\mathrm{df}$ & $\begin{array}{c}\text { Mean } \\
\text { Square }\end{array}$ & $\mathrm{F}$ & Sig. \\
\hline 1 Regression & 684.549 & 6 & 114.092 & 22.083 & $\mathbf{. 0 0 0}^{\mathrm{c}}$ \\
\hline Residual & 103.331 & 20 & 5.167 & & \\
\hline Total & $787.880^{\mathrm{d}}$ & 26 & & & \\
\hline
\end{tabular}

Note: a... Dependent variable: e-working

b... Linear regression through the origin

c... Predictors: ivr, pdi, mas, ltowvs, uai, idv

d... This total sum of squares is not corrected for the

constant because the constant is zero for regression

through the origin.

Source: Author's own compilation

$$
\text { Table 3: ANOVA. }
$$

The results of the tests of individual indicators are presented in Table 4, which shows the dependency of measurement between e-working and selected dimensions. The correlation with e-working is statistically significant at the PDI and IVR indices. With the PDI index, the correlation is negative, i.e. the lower the PDI index, the higher the proportion of e-working. With the IVR index, the correlation is positive, i.e. the higher the IVE index, the higher the proportion of e-working.

The analysis results imply (correlation coefficient - 0.439 PDI) that countries with low power (distance) have a higher proportion of e-working. This indicates that if the extent of power in the national culture is higher, the proportion of e-working drops, as can be seen in Figure 1, where the downward trend can be seen when PDI increases.

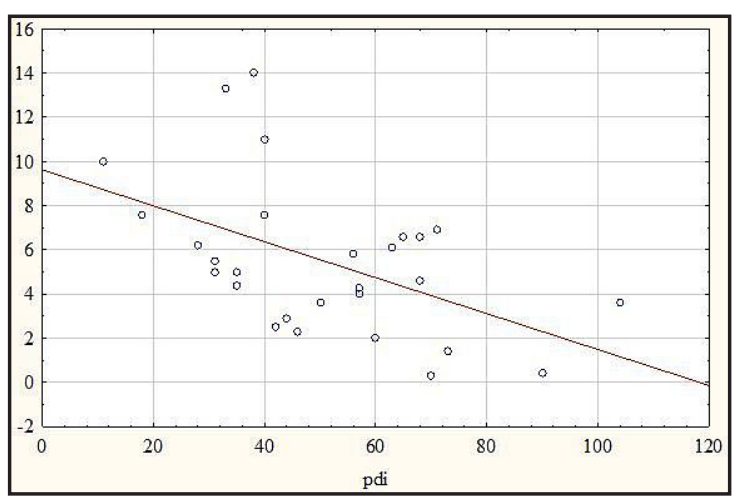

Source: Author's own compilation

Figure 1: Scatterplot of e-working against PDI.

Correlation coefficient 0.696 IVR (see Figure 2) indicates positive dependency between e-working and the importance of happiness, and the control over life, thus Work-Life balance.

\begin{tabular}{|c|c|c|c|c|c|c|c|c|}
\hline \multicolumn{9}{|c|}{ Coefficients ${ }^{\mathrm{a}, \mathrm{b}}$} \\
\hline \multirow{2}{*}{ Model } & & \multicolumn{2}{|c|}{ Unstandardised Coefficients } & \multirow{2}{*}{$\frac{\text { Standardised Coefficients }}{\text { Beta }}$} & \multirow[b]{2}{*}{$\mathrm{t}$} & \multirow[b]{2}{*}{ Sig. } & \multicolumn{2}{|c|}{ Collinearity Statistics } \\
\hline & & B & Std. Error & & & & Tolerance & VIF \\
\hline \multirow{6}{*}{1} & pdi & -.043 & .027 & -.439 & -1.591 & .127 & .086 & 11.590 \\
\hline & idv & -.005 & .031 & -.057 & -.170 & .867 & .058 & 17.324 \\
\hline & mas & .002 & .019 & .017 & .092 & .928 & .192 & 5.198 \\
\hline & uai & .021 & .022 & .291 & .986 & .336 & .075 & 13.296 \\
\hline & ltowvs & .040 & .029 & .428 & 1.343 & .194 & .065 & 15.451 \\
\hline & ivr & .083 & .026 & .696 & 3.138 & .005 & .133 & 7.506 \\
\hline
\end{tabular}

Note: a... Dependent variable: e-working \%

b... Linear regression through the origin

Source: Author's own compilation 


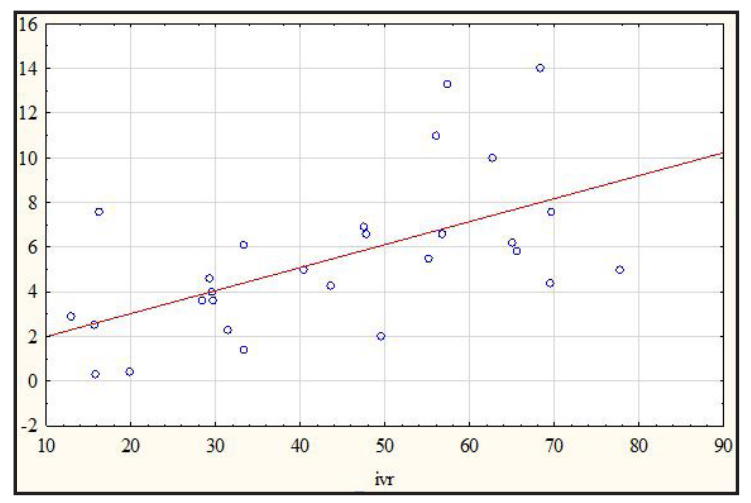

Source: Author's own compilation

Figure 2: Scatterplot of e-working against IVR.

Countries with a high value for individual property (high IVR value) allow their population to meet their basic needs and demands without obstacles (valuing of leisure time, friends, family). On the contrary, with a low index, the degree of dominance increases; people suppress their needs, and complying with strict social standards (leisure time, friends) is of less importance. In simple terms, a high IVR means a higher proportion of e-working, a lower IVR means a low proportion of e-working.

The diversity of cultures in Eastern and Western Europe is a much analysed topic. There are several complex descriptive cultural models (Hofstede, 1980, 1993; Trompenaars, 1993) and theories of cultural standards (Thomas, 1993) that describe intercultural differences between the East and West of Europe in an economic context. Based on the results of correlation, the author tried to summarise the relative positions of world cultures of the countries divided according to cardinal directions (E, W, N and $\mathrm{S}$ ), together with cultural dimensions. This was done in two graphs of intersection axes that form quadrants. The author located the names so that their dimensional coordinates were taken into account. Figure 3 shows the intersection of the dimensions of flat and vertical hierarchies versus well-being and work ethic.

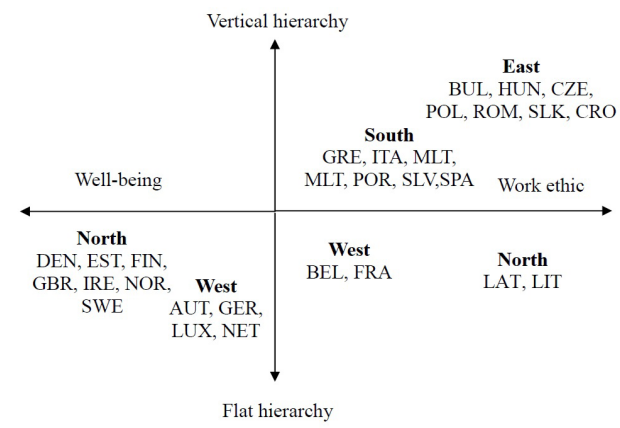

Source: Author's own compilation

Figure 3: Authority versus WLB.
It is interesting to note how countries can rework their work space according to the values of hierarchy and by behaviour, cooperation and mobility. When determining the distance between employees and managers in or outside the office, it can be seen how in Austria hierarchy operates in the same space as employees where the input space of cooperation and the probability of the director moving into such space are accessible. This model would change completely when the working trends of the V4 countries are monitored. The collaborative spaces should then be located prudently so that cooperation is strengthened. In the end, it seems that the current trend focuses on workers' flexibility. It should be noted that e-working is still of great potential in Austria where mobility seems to be accepted. On the contrary, in the V4 countries employees are expected to behave seriously when performing work.

Another feature that influences different proportions of e-working among the monitored countries is well-being, which is also related to the ecological factor. It is generally known that Austria is a pioneer in environmental protection compared to the V4 countries.

This analysis also implies that countries with Germanic languages (Austria, Germany, Great Britain, Ireland, the Netherlands, Sweden, Denmark, Norway, but not Malta, (index 56)) have low indices with a high proportion of e-working compared to countries with Romance languages (France, Portugal, Spain, Italy, Romania) that have medium to high indices, and therefore a medium to low proportion of e-working. Then come countries with mixed Germanic-Romance languages - Belgium, with a higher index and a lower proportion of e-working, and Luxembourg, with a lower index and a high proportion of e-working. The countries with Slavic languages, namely West Slavic (Czech Republic, Slovakia, Poland) and South Slavic (Croatia, Slovenia and Bulgaria) have high indices and thus a lower proportion of e-working. These are followed by the countries with Finno-Ugric languages (Hungary and Estonia) with medium values, where Hungary has a lower proportion of e-working compared to Estonia, due to the technological advancement of the country.

Another possible factor that influences the proportion of e-working in a country is climate (climate change), because a warm climate could encourage more lethargy than temperate and cold climates. Therefore productivity also decreases, and vice versa (Muszynski and Berry, n.d.; Thorpe, 2020). This is connected with the division of economy. People in lower latitudes are more 
dedicated to agricultural or other manual activities than in higher latitudes, where there is less affinity between humans and nature.

As mentioned, the ecological factor together with well-being plays an important role in countries when compared with the proportion of e-working. The basic types of European social model, namely Anglo-Saxon -indicated as liberal (Ireland, Great Britain), continental - indicated as conservative (Germany, France, Austria, Belgium, Luxembourg), Nordic - indicated as social-democratic (Denmark, Finland, Sweden, the Netherlands) and Mediterranean - indicated as a combination of three models (Greece, Italy, Spain, Portugal), can be considered the next factor influencing a higher proportion of this form of work. In connection with EU enlargement, the central (V4) state types - closer to the continental type - and the East European (Baltic) type - where the features of a liberal model prevail - are developed (Alber and Gilbert, 2010; Sapir, 2006).

In key texts by Toffler (1984) and Handy (1984), it is assumed that work from home would be a phenomenon of the future. It seems, however, that their prognosis was far from the reality, as far as its implementation is concerned. Development has not met the expectations globally, nor regionally, as in the case of the countries studied. The V4 countries are actually behind the average of utilisation of this form of work. Theoretically, a large number of persons at many workplaces could basically be allowed to be e-working. In the 1980s, Olson and Primps (1984) suggested that more than $50 \%$ of office work could be done from home, and Steinle (1988) argued that two thirds of job positions could be suitable for e-working for certain persons and employers. Will rural areas necessarily become "remnants of the past inhabited by non-talented losers only" or "will the opportunities provided by the ICT and the changes in the content of occupational duties provide the rural inhabitants an opportunity to be involved in the knowledge economy, which is traditionally linked to metropolitan areas, distantly?" (Nuur and Laestadius 2009; Adamsone et al., 2013). But Covid-19 changed everything. The future of work is suddenly here. Today's office is global and virtual. This pandemic creates an e-working tipping point. Millions of people around the world must now work from home.

However, the Covid-19 outbreak has undermined the way of work with travel restrictions, limitation of the size of meetings, social contacts and selfisolation of workers after return from affected regions. The coronavirus led to the urgent need for the implementation of e-working, increase of digitising, investments in new technologies, more flexibility not only at work, better quality virtual meetings and discussions on business ethics because the demand for e-working would increase in the long term, even after this pandemic. Will Covid-19 change the way we work? Such progress will occur only if societies are able to execute the required complex labour policies, particularly in the period after the pandemic. There are still work activities and tasks that are best suited for personal interaction, and also some workers simply prefer this. However, it will be disappointing if employers and managers do not continue with this change in the workplace after the crisis ends. Covid-19 prompted the largest e-working experiment ever; it has accelerated the future of work and will influence the way we think of work in the years to come. The worst thing society can do would be to ignore what has been learned about the workforce and how workers like to function.

Peters and den Dulk (2003) assumed that the willingness to implement remote work could differ depending on the culture and could be connected with the avoidance of power and ambiguities, which are two cultural dimensions identified by Hofstede as influencing working behaviour. The author agrees with these views on the distribution of power within society and the implementation of e-working, but, based on the findings of this paper, the second dimension is the IVR (Indulgence Versus Restraint) dimension that evaluates the freedom with which people can meet their basic needs and desires for the enjoyment of life.

\section{Conclusion}

The level of e-working is hard to measure, partly because of limited official statistics and because the practice is sometimes carried out at the discretion of local management in the absence of company policy. Furthermore, there is no international statistical definition, often no official e-working policy, and it is a widespread practice operated by employers, usually as part of flexible work policies. However, it is also clear that e-working is a growing phenomenon largely driven by technological change, work demands, the wish to decrease commuting time and the need to maintain WLB and halt the spread of Covid-19. To realise the benefits on a wider scale, to the individual, the employer, the economy and society as a whole, some actions can 
be undertaken to support a greater take-up of e-working.

Cultural differences are a big challenge in the work process globally. People all work differently, and professional expectations as well as cultural values have a significant impact on how workspaces are designed. This analysis dealt with e-working related to cultural values. The overall analysis implies that cultural differences should be taken into account in the implementation of e-working. It should be emphasised that other factors such as tolerance, population density and technological skills must also be considered. In addition to this assessment, it was confirmed that the most important values were separation of private and professional lives (WLB), well-being and the way individuals cooperate on the basis of the importance of hierarchy.

Twenty-eight different cultures with six dimensions were studied in relation to e-working. It is clear that hierarchy is considered culturally less important, and it can be argued that cooperation and support of e-working and well-being are the optimum solution.

According to the World Economic Forum's 2018 report on global competitiveness, the flattest hierarchy in the world, in terms of the index of its willingness to delegate authority, is Denmark. It is followed by Sweden, Norway in 3rd place, Finland in $4^{\text {th }}$ place and the Netherlands $6^{\text {th }}$. In Austria, hierarchy is also important ( $19^{\text {th }}$ place $)$ compared to the V4 countries - Czech Republic (27), Slovakia (59), Poland (84) and Hungary in 88th place (Schwab, 2018).

People in all the studied cultures could work in different ecosystems: in the office, outside the office, virtually or manually, and in other locations. This applies particularly in Nordic and Western countries, where work can be in a different position compared to other monitored cultures that clearly create boundaries between office hours and personal time. In countries where the culture of management is based on control rather than on trust, e.g. France, Spain, Italy, Greece and in the former Eastern Bloc, it seems more logical to manage employees' productivity in offices. This is an interesting finding when one realises that Spain is the fifth most cooperative space per inhabitant and France is the 9th (Coop, 2016). Trust leads to cooperation, which means countries that have management based on trust are more willing to attract cooperation, e.g. Norway, Finland, Great Britain, Sweden, Luxembourg, Germany, Denmark, Estonia and Belgium (Coop, 2016).
The results of a happy community with an evaluation of happiness (evaluation of life, positive and negative influence in 2016 - 2018) that also has a great influence on the proportion of e-working are interesting too. Finland is ranked top, Denmark in $2^{\text {nd }}$ place, the Netherlands $5^{\text {th }}$, Norway $6^{\text {th }}$, Sweden $7^{\text {th }}$ and Austria $10^{\text {th }}$. The V4 countries are: Czech Republic 20 $0^{\text {th }}$, Slovakia in $38^{\text {th }}$ place, Poland $40^{\text {th }}$ and Hungary in $62^{\text {nd }}$ place (Helliwell et al., 2019). An assessment of OECD countries in terms of WLB (how much do you work?, how much do you play?) has confirmed the results of this analysis: The Nordic countries where e-working has more support have higher values. An interesting finding was that countries such as Italy $(9.4 \%)$, Spain (8.8\%), Lithuania (8.3\%), Hungary (8.0\%), Slovakia (7.9\%) and the Czech Republic (7.6\%) with their lower proportion of e-working show higher values of WLB interest. Austria and Poland have an equal value of $6.8 \%$ (OECD, n.d.). This implies that these countries are not making use of the basic information on the advantages of this form of work, from an educational sphere to a practical sphere. The hierarchy of organisations, which is connected with trust within the society and subsequent cooperation, needs to be adjusted. Population ageing, climate change, pandemics, the generation gap and attributes in life will also have a significant impact on the development. Therefore rural development policies that support e-working could be helpful to sustain highly skilled employees outside urban and suburban areas and increase economic, social and cultural activities. Salemink et al. (2015) highlight that rural communities are most in need of improved digital connectivity to compensate for their remoteness. Gallup Poll discovered that many urban residents would like to make a move to rural America: $27 \%$ said a rural area would be their ideal community, while only $12 \%$ responded that they prefer a big city. The remaining 39\% would choose a town, a small city or a suburb of a small city (Newport, 2018).

To achieve sustainability, rural development requires e-working models that are designed in and for local needs. If we want to work successfully with people from other cultures, we have to consider the specifics of the different cultures and develop a shared understanding of the common task and of working together. There is no one-size-fits-all model that can be used always and everywhere. Every case and every team constellation is unique and must be treated as such. 
Corresponding authors

Mgr. Bc. Michal Beňo, PhD.

Institute of Technology and Business in České Budějovice

Okružni 517/10, 370 České Budějovice, Czech Republic

E-mail:28265@mail.vstecb.cz

\section{References}

[1] Adamsone, L., Baltina, I., Judrupa, I., Senfelde, M. and Vitola, A. (2013) "Overview on the Smart Work Centres in Europe". [Online]. Available: http://www.micropol-interreg.eu/IMG/pdf/ Overview_of_Smart_Work_Centres_in_Europe-2.pdf [Accessed: 12 Nov. 2020].

[2] Alber, J. and Gilbert, N. (2010) "United in Diversity? Comparing Social Models in Europe and America", Oxford, Oxford University Press, p. 439. ISBN 978-019-537663-0.

[3] Bates, P., Bertin, I. and Huws, U. (2002) "E-work in Ireland". [Online]. Available: https://www. employment-studies.co.uk/system/files/resources/files/394.pdf [Accessed: 14 Oct. 2020].

[4] BBC (2000) "Overworked? Try a virtual assistant". [Online]. Available: http://news.bbc.co.uk/2/ hi/business/930536.stm [Accessed: 14 Oct. 2020].

[5] Becke, J., Ballentine, R., Tedford, K. and Lee, A. (2001) "Best Practices for Managing Collaborative Technology Tools and Virtual Teams”, AMCIS 2001 Proceedings, 122, pp. 614-617.

[6] Beňo, M. (2018a) "Working in the Virtual World - an approach to the Home Office Business Model Analysis", Ad Alta: Journal of Interdisciplinary Research, Vol. 8, No. 1, pp. 25-36. ISSN 1804-7890.

[7] Beno, M. (2018b) "Transformation of Human Labour from Stone Age to Information Age", In: Younas, M., Awan, I., Ghinea, G., and Catalan Cid, M. (eds) "Mobile Web and Intelligent Information Systems", MobiWIS 2018, Lecture Notes in Computer Science, Vol. 10995. Springer, Cham. E-ISBN 978-3-319-97163-6, ISBN 978-3-319-97162-9. DOI 10.1007/978-3-319-97163-6_17.

[8] Beňo, M. (2021a) "The Advantages and Disadvantages of E-working: An Examination using an ALDINE Analysis", Emerging Science Journal, Vol. 5, pp. 11-20. ISSN 2610-9182. DOI 10.28991/esj-2021-SPER-02.

[9] Beno, M. (2021b) “Analysis of Three Potential Savings in E-Working Expenditure", Frontiers in Sociology, Vol. 6, No. 675530, pp. 1-8. E-ISSN 2297-7775. DOI 10.3389/fsoc.2021.675530.

[10] Beňo, M. and Ferenčíková, S. (2019) “The Future of Work is e-Work”, IWKM 2019, 7 - 8 November 2019, Bratislava - Trenčín, Slovakia, pp. 6-20.

[11] Beno, M. and Hvorecky, J. (2021) "Data on an Austrian Company's Productivity in the Pre-Covid-19 Era, During the Lockdown and After Its Easing: To Work Remotely or Not?", Frontiers in Communication, Vol. 6, No. 641199, pp. 1-10. E-ISSN 2297-7775. DOI 10.3389/fcomm.2021.641199.

[12] Bishop, K. (2020) "Helsinki shows how a city embraces remote work", [Online]. Available: https://citymonitor.ai/economy/to-see-how-a-city-embraces-remote-work-look-to-helsinki/ [Accessed: 12 Nov. 2020].

[13] Brennan, M. A., Flint, C. G. and Luloff, A. E. (2009) "Bringing together local culture and rural development: findings from Ireland, Pennsylvania and Alaska", Sociologia Ruralis, Vol. 49, No. 1, pp. 97-112. ISSN 1467-9523. DOI 10.1111/j.1467-9523.2008.00471.x.

[14] Brette, O. and Moriset, B. (2009) "Bringing Down Territorial Inequalities in the Digital Economy: An Evolutionary Institutional Approach”, Journal of Economic Issues, Vol. 43, No. 2, pp. 495-502. E-ISSN 1946-326X, ISSN 0021-3624. DOI 10.2753/JEI0021-3624430223.

[15] Coop (2016) "The International Prevalence of Co-operative Values". [Online]. Available: https://www.uk.coop/sites/default/files/uploads/attachments/the_international_prevalence_of_ cooperative_values.pdf [Accessed: 14 Oct. 2020]. 
[16] Davies, A. (2021) "COVID-19 and ICT-Supported Remote Working: Opportunities for Rural Economies”, World, Vol. 2, No. 1, pp. 139-152. E-ISSN 2673-4060. DOI 10.3390/world2010010.

[17] Derks, D. and Bakker, A. B. (2010) "The Impact of E-mail Communication on Organizational Life", Cyberpsychology: Journal of Psychological Research on Cyberspace, Vol. 4, No. 1, pp. 1-14. ISSN 1802-7962.

[18] Dimitrov, K. (2014) “Geert Hofstede et al's Set of National Cultural Dimensions - Popularity and Criticisms", Economics Alternatives Journal, Vol. 2, pp. 30-60. E-ISSN 2367-9409, ISSN 1312-7462.

[19] Dunn, H. S. (2009a) "Teleworking the Mobile Caribbean: Enabling Remote Work Among the Marginalized in Jamaica and Trinidad and Tobago", Information Technologies and International Development, Vol. 5, No. 2, pp. 52-66. ISSN 1544-7529.

[20] Dunn, H. S. (2009b) "From voice ubiquity to mobile broadband: challenges of technology transition among low-income Jamaicans”, Info, Vol. 11; No. 2, pp. 96-111. ISSN 1463-6697. DOI 10.1108/14636690910941911.

[21] Eurostat (2019) "Employed persons working from home as a percentage of the total employment, by sex, age and professional status (\%)". [Online]. Available: http://appsso.eurostat.ec.europa.eu/ nui/submitViewTableAction.do. [Accessed: 10 Nov. 2020].

[22] Frempong, G. (2009) "Mobile telephone opportunities: the case of micro- and small enterprises in Ghana”, Info, Vol. 11, No. 2, pp. 79-94. ISSN 1463-6697 . DOI 10.1108/14636690910941902.

[23] Gallardo, R. and Florida, R. (2020) "Remote Work and the Coronavirus". [Online]. Available: https://pcrd.purdue.edu/remote-work-and-the-coronavirus/ [Accessed: 12 Nov. 2020].

[24] Geert Hofstede (2015) "The IWG Global Workspace Survey. Welcome to Generation Flex-the employee power shift". [Online]. Available: https://geerthofstede.com/research-and-vsm/ dimension-data-matrix/ [Accessed: 14 Oct. 2020].

[25] Handy, C. (1984) “The Future of Work”, Oxford, Basil Blackwell, p. 216. ISBN 0-85520-688-8.

[26] Helliwell, J. F. and Layard, R. and Sachs, J. D. (2019) "World Happiness Report". [Online]. Available: https://worldhappiness.report/ed/2019/ [Accessed: 14 Oct. 2020].

[27] Hofstede, G. (1980) “Culture’s consequences”, Beverly Hills, Sage, p. 328.

[28] Hofstede, G. (1991) "Cultures and organizations: Software of the mind. Intercultural Cooperation and its Importance for Survival”, New York, McGraw-Hill, p. 296. ISBN 0-07-029307-4.

[29] Hofstede, G. (1993) "Interkulturelle Zusammenarbeit - Kulturen-Organisationen-Management”, Wiesbaden, Gabler, p. 328. ISBN 9783409131575. DOI 10.1007/978-3-322-90037-1. (In German).

[30] Hofstede, G., Hofstede, G. J. and Minkov, M. (2010) “Cultures and organizations: Software of the mind: Intercultural cooperation and its importance for survival", New York, McGraw-Hill, p. 576. ISBN 978-0-07-166418-9.

[31] IWG (2019) "The IWG Global Workspace Survey. Welcome to Generation Flex-the employee power shift". [Online]. Available: https://assets.regus.com/pdfs/iwg-workplace-survey/iwg-workplacesurvey-2019.pdf [Accessed: 14 Oct. 2020].

[32] Jones, M. and Alony, I. (2007) "The Cultural Impact of Information Systems- Through The Eyes of Hofstede- A Critical Journey", Issues in Informing Science and Information Technology, Vol. 4, pp. 407-419. ISSN 1547-5867. DOI 10.28945/960.

[33] Kalika, M. and Jawadi, N. (2008) "Impacts of team virtuality on performance: a qualitative study, European and Mediterranean Conference on Information Systems”, EMCIS 2008, May 25-26 2008, Al Bustan Rotana Hotel, Dubai, pp. 1-13.

[34] Karoui, M., Gürkan, A. and Dudezert, A. (2010) "Virtual Team Collaboration: A Review of Literature and Perspectives", AMCIS 2010 Proceedings, No. 81, pp. 1-13. 
[35] Karpova, E., Correia, A. P. and Baran, E. (2009) "Learn to use and use to learn: Technology in virtual collaboration experience", Internet and Higher Education, Vol. 12, No. 1, pp. 45-52. ISSN 1096-7516. DOI 10.1016/j.iheduc.2008.10.006.

[36] Kirkman, B. L. and Mathieu, J. E. (2005) "The dimensions and antecedents of team virtuality", Journal of Management, Vol. 31, No. 5, pp. 700-718. ISSN 1557-1211, ISSN 0149-2063. DOI $10.1177 / 0149206305279113$.

[37] Kirkman, B. L., Lowe, K. B. and Gibson, C. B. (2006) “A quarter century of Culture's Consequences: A review of empirical research incorporating Hofstede's cultural values framework", Journal of International Business Studies, Vol. 37, No. 3, pp. 285-320. E-ISSN 1478-6990, ISSN 0047-2506. DOI 10.1057/palgrave.jibs.8400202.

[38] Merkin, R., Taras, V. and Steel, P. (2014) "State of the art themes in cross-cultural communication research: A systematic and meta-analytic review", International Journal of Intercultural Relations, Vol. 38, No. 1, pp. 1-23. ISSN 0147-1767. DOI 10.1016/j.ijintrel.2013.10.004.

[39] Messenger, J. C. and Gschwind, L. (2016) "Three generations of Telework: New ICTs and the (R) evolution from Home Office to Virtual Office", New Technology, Work and Employment, Vol. 31, No. 3, pp. 195-208. E-ISSN 1468-005X. DOI 10.1111/ntwe.12073.

[40] Mihhailova, G., Kandela, O. and Turk, K. (2009) "Virtual work and its challenges and types", The Business Review Cambridge, Vol. 12, No. 2, pp. 96-103.

[41] Muszynski, Ch. and Berry, K. (n.d.) "It Is Hot, It Is Cold, It Is Climate". [Online]. Available: http://umich.edu/ gs265/climate.htm [Accessed: 14 Oct. 2020].

[42] Newport, F. (2018) "Americans Big on Idea of Living in the Country". [Online]. Available: https://news.gallup.com/poll/245249/americans-big-idea-living-country.aspx [Accessed: 12 Nov. 2020].

[43] Nuur, C. and Laestadius, S. (2009) "Is the 'Creative Class'Necessarily Urban? Putting the Creativity Thesis in the Context of Non-urbanised Regions in Industrialised Nations". [Online]. Availabl: https://archive.nordregio.se/Global/EJSD/debate200906.pdf [Accessed: 12 Nov. 2020].

[44] OECD (n.d.) "Work-Life Balance". [Online]. Available http://www.oecdbetterlifeindex.org/topics/ work-life-balance/ [Accessed: 14 Oct. 2020].

[45] Olson, M. H. (1983) "An Investigation of the Impacts of Remote Work Environments and Supporting Technology". [Online]. Available https://ssrn.com/abstract=1290123 [Accessed: 25 May 2021].

[46] Olson, M. H. and Primps, S. B. (1984) "Working at Home with Computers: Work and Nonwork Issues", Journal of Social Social Issues, Vol. 40, No. 3, pp. 97-112. E-ISSN 1540-4560. DOI 10.1111/j.1540-4560.1984.tb00194.x.

[47] Pearce, J. A. II (2009) "Successful Corporate Telecommuting with Technology Considerations for Late Adopters", Organizational Dynamics, Vol. 38, No. 1, pp. 16-25. ISSN 0090-2616. DOI 10.1016/j.orgdyn.2008.10.002.

[48] Peters, P. and den Dulk, L. (2003) "Cross-cultural differences in managers' support for homebased telework: A theoretical elaboration", International Journal of Cross Cultural Management: CCM, Vol.3,No.3,pp.329-346.E-ISSN 1741-2838, ISSN 1470-5958. DOI 10.1177/1470595803003003005.

[49] Philip, L. and Williams, F. (2019) "Remote rural home based businesses and digital inequalities: Understanding needs and expectations in a digitally underserved community", Journal of Rural Studies, Vol. 68, pp. 306-318. ISSN 0743-0167. DOI 10.1016/j.jrurstud.2018.09.011.

[50] Plauché, M. and Prabaker, M. (2006) "Tamil Market: A Spoken Dialog System for Rural India", In Proceedings of CHI 2006, 22-27 April 2006, Montreal, Quebec, Canada. [Online]. Available: http://www.icsi.berkeley.edu/pubs/speech/tamil-market.pdf [Accessed: 12 Nov. 2020].

[51] PWC (2020) "The COVID-19 Remote Working Experiment". [Online]. Available: https://www.pwc. $\mathrm{com} / \mathrm{mt} / \mathrm{en} /$ publications/the-covid19-remote-working-experiment-final4.pdf [Accessed: 25 May 2021]. 
[52] Redfin (2020) "Interest in Rural Areas and Small Towns Spikes During the Coronavirus Outbreak". [Online]. Available: https://www.redfin.com/news/urban-vs-rural-homebuyer-interest-coronavirus/ [Accessed: 12 Nov. 2020].

[53] Salemink, K., Strijker, D. and Bosworth, G. (2015) "Rural development in the digital age: A systematic literature review on unequal ICT availability, adoption, and use in rural areas", Journal of Rural Studies, Vol. 54, pp. 360-371. ISSN 0743-0167. DOI 10.1016/j.jrurstud.2015.09.001.

[54] Sapir, A. (2006) "Globalization and Reform of the European Social Model", Journal of Common Market Studies, Vol. 44, No. 2, pp. 369-390. E-ISSN 1468-5965. DOI 10.1111/j.1468-5965.2006.00627.x.

[55] Savage, M. (2019) "Why Finland leads the world in flexible work?". [Online]. Available: https://www.bbc.com/worklife/article/20190807-why-finland-leads-the-world-in-flexible-work [Accessed: 14 Oct. 2020].

[56] Schwab, K. (2018) “The Global Competitiveness Report 2017-2018”. [Online]. Available: http://www3.weforum.org/docs/GCR2017-2018/05FullReport/TheGlobalCompetitiveness Report2017\%E2\%80\%932018.pdf [Accessed: 14 Oct. 2020].

[57] Sisson, P. (2019) "Reversing the rural brain drain with remote working". [Online]. Available: https://archive.curbed.com/2019/2/12/18221421/startup-remote-working-rural-coworking [Accessed: 12 Nov. 2020].

[58] Søndergaard, M. (1994) "Hofstede's Consequences: A study of reviews, citations and replications", Organization Studies, Vol. 15, No. 3, pp. 447-456. E-ISSN 1741-3044. ISSN 0170-8406. DOI 10.1177/017084069401500307.

[59] Soyez, F. (2019) "Management: Le bureau statutaire a-t-il encore de l'avenir?". [Online]. Available: http:/courriercadres.com/entreprise/recherche-innovation/management-le-bureau-individuel-etstatutaire-a-t-il-encore-de-lavenir-21032019 [Accessed: 14 Oct. 2020]. (In French).

[60] Steinle, W. J. (1988) “Telework: Opening Remarks on an Open Debate”, Telework: Present Situation and Future Development of a New Form of Work Organization edited by Werner B. Korte, Simon Robinson and Wolfgang Steinle. New York, Elsevier Science Publishing, 8 p.

[61] The World Bank (2018) "Rural population (\% of total population)". [Online]. Available: https://data.worldbank.org/indicator/SP.RUR.TOTL.ZS?name_desc=false [Accessed: 12 Nov. 2020].

[62] Thomas, A. (1993) "Kulturvergleichende Psychologie”, Göttingen, Hogrefe, p. 450. ISBN 978-3801704087. (In German).

[63] Thorpe, J. R. (2020) "Does Hot Weather Make You Lazy? There's A Scientific Explanation Why You Slow Down In The Summer". [Online]. Available: https://www.bustle.com/p/does-hot-weathermake-you-lazy-theres-a-scientific-explanation-why-you-slow-down-in-the-summer-9273543 [Accessed: 14 Oct. 2020].

[64] Toffler, A. (1984) “The Third Wave”, US, Bantam Books, p. 560. ISBN 0-553-24698-4.

[65] Trompenaars, F. (1993) "Handbuch globales Managen. Wie man kulturelle Unterschiede im Geschäftsleben versteht”, Düsseldorf, Econ, p. 271. ISBN 978-3430191357. (In German).

[66] Vilhelmson, B. and Thulin, E. (2016) "Who and where the flexible workers? Exploring the current diffusion of telework in Sweden", New Technology, Work and Employment, Vol. 31, No. 1, pp. 77-96. E-ISSN 1468-005X. DOI 10.1111/ntwe.12060.

[67] Vitola, A. and Baltina, I. (2013) "An Evaluation of the Demand for Telework and Smart Work Centres in Rural Areas: A Case Study from Latvia”, European Countryside, Vol. 5, No. 3, pp. 251-264. E-ISSN 1803-8417. DOI 10.2478/euco-2013-0016.

[68] WDC (2017) "e-Working in the Western Region". [Online]. Available: https://www.wdc.ie/wpcontent/uploads/WDC_Policy-Briefing-no-7.pdf [Accessed: 14 Oct. 2020].

[69] Ye, L. R. (2012) “Telecommuting: Implementation for Success”, International Journal of Business and Social Science, Vol. 3, No. 15, pp. 20-29. 